Volume 1 Issue 1, March 2017: pp. 105-123. Copyright (c) 2017 HOLREV. Faculty of Law, Halu Oleo University, Kendari, Southeast Sulawesi, Indonesia. ISSN: 2548-1762 I e-ISSN: 2548-1754. Open Access at: http://ojs.uho.ac.id/index.php/holrev/

Halu Oleo Law Review is licensed under a Creative Commons Attribution 4.0 International License, which permits unrestricted use, distribution, and reproduction in any medium, provided the original work is properly cited.

\title{
Kewenangan Hakim Mengadili Sengketa Kontrak
}

\author{
The Power of Judges' Decision-Making on Contractual Dispute
}

\author{
Mohammad Zamroni \\ Fakultas Hukum, Universitas Hang Tuah \\ E-mail: zamrolaw@gmail.com
}

\begin{abstract}
Dispute resolution of contract has become an effort to cap off the conflict or differences of interest that might occur when the contract begin. With an end to a conflict, so each group is able to continue contractual relation or that may return to previous contract. Nevertheless, each group was unable to find out solution upon conflict, so that this problem was carried oftentimes on the Judges. Problem point, principle of contract as well as principle of pacta sunt servanda stated that outside of each group cannot interfere what have been agreed among the parties. Intervention upon the contract was bothered a legal certainty. This research aimed to analyze legal power of Judge who has adjudicated dispute contract. By using legal research method, this method was consisted of statute and conceptual approach. This study has revealed that the power of Judge's decision-making on dispute contract considerably based on the object of contract namely to protect each party dispute by applying legal protection fairly, and enforcing legal certainty toward what has been disputed.
\end{abstract}

Keywords: Power of Judge, Dispute Contract.

Abstrak: Penyelesaian sengketa kontrak merupakan upaya untuk mengakhiri konflik atau perbedaan kepentingan yang muncul pada saat pelaksanaan kontrak. Dengan diakhirinya suatu konflik, maka para pihak dapat kembali melanjutkan hubungan kontraktual, atau kembali kepada keadaan seperti sebelum mengadakan hubungan kontraktual. Namun demikian para pihak sering kali tidak mampu menemukan solusi bersama atas konflik yang terjadi, sehingga penyelesaiannya kemudian diserahkan kepada hakim. Masalahnya, asas kebebasan berkontrak dan asas pacta sunt servanda telah menegaskan bahwa pihak-pihak di luar kontrak tidak dapat mencampuri apa yang telah disepakati para pihak. Sehingga adanya intervensi terhadap kontrak dianggap mengganggu kepastian hukum. Penelitian ini bertujuan untuk mengkaji dasar kewenangan hakim mengadili sengketa kontrak. Penelitian ini adalah menggunakan metode penelitian hukum, serta melalui pendekatan perundang-undangan dan pendekatan konseptual, hasil penelitian ini menunjukkan bahwa kewenangan hakim mengadili sengketa kontrak didasarkan pada tujuan hukum kontrak, yaitu untuk mengayomi 
pihak-pihak yang bersengketa, dengan memberikan perlindungan terhadap kepentingan para pihak secara adil, dan memberikan kepastian hukum terhadap kontrak yang disengketakan.

Kata kunci: kewenangan hakim; sengketa; kontrak

\section{PENDAHULUAN}

Sengketa kontrak terjadi karena para pihak tidak lagi dapat menemukan solusi bersama untuk menyelesaikan perbedaan yang muncul pada tahap pelaksanaan kontrak. Meskipun kontrak berlaku mengikat laksana undang-undang, ketika terjadi sengketa, pelaksanaan kontrak menjadi tidak jelas. Masing-masing pihak tidak lagi secara sukarela melaksanakan prestasi yang telah diperjanjikan. Pada titik ini kontrak hanyalah macan kertas yang tidak memberikan kepastian hukum. Sehingga pihak yang merasa dirugikan kemudian berupaya mendapatkan kepastian hukum melalui Pengadilan.

Pada awalnya Mahkamah Agung menolak setiap intervensi hakim terhadap kontrak yang telah disepakati para pihak. Hal ini didasarkan pada asas kebebasan berkontrak dan asas pacta sunt servanda yang mengikat kedua belah pihak. Pandangan Mahkamah Agung ini terekam dalam yurisprudensi Mahkamah Agung dalam perkara Ida Ayu Suryani melawan I Nyoman Sudirja. ${ }^{1}$ Klausul-klausul yang telah disepakati bersama dalam kontrak dianggap mengikat dan berlaku sebagai undang-undang bagi kedua belah pihak. Sehingga para pihak tidak memiliki alasan lain selain melaksanakan apa yang telah diperjanjikan. Pandangan serupa terlihat dalam perkara Can Thiam Song melawan Cia Khun Chai. ${ }^{2}$ Menurut Mahkamah Agung, para pihak harus menaati klausul yang telah disepakati dan dikukuhkan dalam akta autentik.

Dari putusan di atas terlihat Mahkamah Agung konsisten dengan yurisprudensi yang ada, yaitu hanya mendasarkan kontrak pada asas kebebasan berkontrak dan asas pacta sunt servanda semata. Mahkamah Agung tidak berusaha mengintervensi apa yang telah disepakati oleh para pihak, meskipun realitasnya bertentangan dengan asas kepatutan dan nilai-nilai hukum yang hidup dalam masyarakat. Akan tetapi sejak tahun 1976, dipengaruhi oleh ajaran Islam - yang dianut oleh mayoritas masyarakat Aceh yang mengharamkan riba, Mahkamah Agung mulai melakukan intervensi terhadap kontrak, yaitu dengan menerapkan asas kepatutan dalam menafsirkan kontrak. 
Dalam perkara Zainal Abidin melawan A.M. Mohamad Zainuddin dkk., ${ }^{3}$ Mahkamah Agung sependapat dengan pertimbangan hukum Pengadilan Negeri Lhokseumawe dan Pengadilan Tinggi Banda Aceh yang menganggap klausul bunga 20\% sebulan yang disepakati dalam kontrak bertentangan dengan nilai-nilai keadilan dan perikemanusiaan. Mahkamah Agung terlihat mulai melakukan intervensi terhadap kontrak yang dianggapnya tidak adil dan bertentangan dengan nilai-nilai yang hidup di masyarakat. Mahkamah Agung berpendapat bahwa asas kebebasan berkontrak tidak bersifat mutlak, yang berarti dalam keadaan tertentu, hakim berwenang melakukan penafsiran hukum. ${ }^{4}$

Pada dasarnya hakim diberikan kewenangan oleh undang-undang untuk mengadili dan memutus setiap sengketa yang dihadapkan kepadanya, termasuk sengketa kontrak. Namun demikian, meskipun hakim memiliki kewenangan untuk mengadili dan memutus sengketa kontrak, tentunya kewenangan tersebut bukan tanpa batas. Karena apabila kontrak dapat ditafsirkan secara bebas dan tanpa batas, maka kontrak tidak lagi memiliki kepastian hukum. Hukum kontrak sendiri didasarkan pada prinsip-prinsip yang menegaskan kekuatan mengikat kontrak. ${ }^{5}$ Prinsip-prinsip ini dikenal sebagai asas kebebasan berkontrak (freedom of contract) dan asas daya mengikat kontrak (pacta sunt servanda). ${ }^{6}$ Kedua asas ini merupakan landasan utama bagi kebebasan dan kepastian hukum dalam kontrak, yaitu kebebasan untuk membuat atau tidak membuat kontrak, ${ }^{7}$ dan kepastian hukum untuk memaksakan kewajiban bagi pihak-pihak yang telah

3 Putusan Mahkamah Agung R.I. No. 1253 K/Sip/1973, tanggal 14 Oktober 1976.

4 Lihat putusan Mahkamah Agung R.I. No. 3641 K/PDT/2001, tanggal 11 September 2001, dalam perkara Made Oka Masagung melawan PT Bank Artha Graha, dkk.

5 Lihat Arthur S. Hartkamp, Marianne M.M. Tillema and Annemarie E.B. ter Heide, Contract Law in the Netherlands, Kluwer Law International, Alphen aan den Rijn, 2011, p. 34, yang menulis contract law is based on several principles which explain the binding force of contract or the necessary conditions for such binding force.

6 Perhatikan Pasal 1338 ayat (1) BW yang menyebutkan, "semua perjanjian yang dibuat secara sah berlaku sebagai undang-undang bagi mereka yang membuatnya." Menurut Subekti, dengan menekankan pada kata "semua" yang ada di muka perkataan "perjanjian", maka dapat disimpulkan adanya asas kebebasan berkontrak. Lihat R. Subekti, Aneka Perjanjian, Cet. Kesepuluh, Citra Aditya Bakti, Bandung, 1995, h. 4-5. Sedangkan menurut Salim, pada kalimat "Perjanjian yang dibuat secara sah berlaku sebagai undang-undang", dapat disimpulkan adanya asas pacta sunt servanda yang berkaitan dengan akibat perjanjian. Lihat Salim HS., Pengantar Hukum Perdata Tertulis (BW), Cet. Kesembilan, Sinar Grafika, Jakarta, 2014, h. 158. (selanjutnya disebut Salim HS I). Istilah Pacta sunt servanda sendiri berarti perjanjian harus diatati. Lihat Peter Mahmud Marzuki, "Batas-Batas Kebebasan Berkontrak", Yuridika, Vol. 18 No. 3, Mei 2003, h. 199. (selanjutnya disebut Peter Mahmud Marzuki I).

7 Lihat J.H. Nieuwenhuis, Drie Beginselen van Contractenrecht, Kluwer, Deventer, 1979, p. 6. (selanjutnya disebut J.H. Nieuwenhuis I), yang menulis inti dari kebebasan berkontrak adalah het recht laat de partijen een kring waarbinnen zij naar vrije verkiezing overeenkomsten mogen aangaan. Lihat juga J.H. Nieuwenhuis, Pokok-Pokok Hukum Perikatan, Terjemahan Djasadin Saragih, Universitas Airlangga, Surabaya, 1985, h. 83. (selanjutnya disebut J.H. Nieuwenhuis II), yang menulis bahwa di dalam asas kebebasan berkontrak terkandung dua macam kebebasan, yaitu kebebasan menurut bentuk dan kebebasan menurut isi. 
membuat kontrak. ${ }^{8}$ Beranjak pada eksplikasi di atas, maka penting untuk dilakukan penelitian terhadap dasar kewenangan hakim mengadili sengketa kontrak.

\section{METODE PENELITIAN}

Mengingat ilmu hukum bersifat sui generis, maka penelitian ini menggunakan metode penelitian hukum. Sedangkan pendekatan yang digunakan adalah pendekatan perundang-undangan (statute approach) dan pendekatan konseptual (conceptual approach). Hal ini beranjak pada pola civil law system dimana hukum utamanya adalah legislasi (reasoning based on rules). Penelusuran peraturan perundang-undangan terutama difokuskan untuk menemukan dasar kewenangan hakim mengadili sengketa kontrak.

Bahan hukum dalam penelitian ini meliputi bahan hukum primer dan bahan hukum sekunder. Bahan hukum primer berupa peraturan perundang-undangan, antara lain; Undang-Undang Nomor 30 Tahun 1999 tentang Arbitrase dan Penyelesaian Sengketa, Undang-Undang Nomor 48 Tahun 2009 tentang Kekuasaan Kehakiman, dan Undang-Undang Nomor 2 Tahun 1986 tentang Peradilan Umum, sebagaimana telah diubah terakhir dengan Undang-Undang Nomor 49 Tahun 2009 tentang Perubahan Kedua Atas Undang-Undang Nomor 2 Tahun 1986 tentang Peradilan Umum. Sedangkan bahan hukum sekunder di antaranya tulisan-tulisan hukum dalam buku teks, jurnal, naskah akademis, makalah, dan dokumen-dokumen lain yang berkaitan.

Penelitian ini berbasis kepustakaan (library based) termasuk juga perpustakaan internet (digital library). Pengumpulan bahan-bahan hukum diawali dengan inventarisasi bahan hukum, kemudian diidentifikasi menggunakan pendekatan penelitian. Bahan hukum yang telah dikumpulkan selanjutnya dianalisis secara kritis dan sistematis.

8 Lihat Salim HS, Hukum Kontrak : Teori \& Teknik Penyusunan Kontrak, Cet. Kesepuluh, Sinar Grafika, Jakarta, 2014, h. 10. (selanjutnya disebut Salim HS II), yang menulis bahwa berdasarkan asas pacta sunt servanda, maka hakim atau pihak ketiga harus menghormati substansi kontrak yang dibuat oleh para pihak sebagaimana layaknya sebuah undang-undang, dan tidak boleh melakukan intervensi terhadap substansi kontrak yang dibuat oleh para pihak. Lihat juga Ridwan Khairandy, "Landasan Filosofis Kekuatan Mengikatnya Kontrak", Jurnal Hukum, No. Edisi Khusus Vol. 18, Oktober 2011, h. 37-38, yang menulis bahwa sebagai konsekuensi dari asas pacta sunt servanda, maka hakim maupun pihak ketiga tidak boleh mencampuri isi perjanjian yang dibuat para pihak. 


\section{ANALISIS DAN PEMBAHASAN}

\section{Hakikat Kewenangan Hakim Mengadili Sengketa Kontrak}

Gustav Radbruch dalam karyanya Einfuhrung indie Rechtswissenschaft menyatakan bahwa sesuatu yang dibuat pasti memiliki cita atau tujuan. Demikian halnya dengan hukum. ${ }^{9}$ Meuwissen mengemukakan bahwa di dalam filsafat hukum terdapat perbedaan pemahaman yang besar mengenai ide hukum (cita hukum). Sebagai tujuan dari hukum sering ditunjuk ketertiban, perdamaian, harmoni, prediktabilitas, hal dapat diperhitungkan, dan kepastian hukum. Sebagian juga memandang penting persamaan dan keadilan. ${ }^{10}$

Menurut Aristoteles, tujuan hukum adalah untuk mencapai kehidupan yang baik. Untuk memperoleh kehidupan yang baik itu diperlukan hukum. Akan tetapi manakala hukum terlalu kaku, dilakukan pelunakan yang disebut equity. Aristoteles mendefinisikan equity sebagai "koreksi terhadap hukum apabila hukum itu kurang tepat karena bersifat umum. Pandangan Aristoteles ini selanjutnya diadopsi oleh Thomas Aquinas dan dikembangkan lebih jauh pada abad pertengahan. Thomas Aquinas menyatakan bahwa secara ideal, hukum terpancar dari kekuasaan untuk memerintah guna kebaikan bersama. ${ }^{11}$

Berbeda dengan Aristoteles dan Thomas Aquinas, Thomas Hobbes justru memandang tujuan hukum secara kaku. Menurut Hobbes, tujuan hukum adalah untuk menciptakan ketertiban sosial. Agar ketertiban tercipta, semua orang harus menyerahkan hak-haknya kepada seseorang yang berkuasa secara absolut. ${ }^{12}$ Pandangan Hobbes ini dikritisi oleh Peter Mahmud Marzuki. Ia mengemukakan bahwa yang dimaksud keadaan tidak kacau balau sebenarnya bukannya tertib (order), melainkan damai sejahtera (peace). Karena dalam situasi ketertiban, pemerintah akan bersikap represif dan otoriter. Selain itu dalam situasi ketertiban tidak dimungkinkan adanya perbedaan pendapat karena akan mengganggu ketertiban. Hal ini berbeda dengan situasi yang damai sejahtera. Hukum akan melindungi kepentingan manusia baik secara materiel maupun imateriel dari perbuatan-perbuatan yang merugikan. Dalam situasi yang damai sejahtera, apabila terdapat perbedaan pendapat, diarahkan kepada

\footnotetext{
9 Muhammad Erwin, Filsafat Hukum Refleksi Kritis Terhadap Hukum, RajaGrafindo, Jakarta, 2011, h. 123.

10 Meuwissen, Tentang Pengembangan Hukum, Ilmu Hukum, Teori Hukum, dan Filsafat Hukum, Terjemahan B. Arief Sidharta, Refika Aditama, Bandung, 2013, h. 37.

11 Lihat Peter Mahmud Marzuki, Pengantar Ilmu Hukum, Edisi Revisi, Kencana Prenada Media Group, Jakarta, 2013, h. 95-96. (selanjutnya disebut Peter Mahmud Marzuki II).

12 Ibid., h. 101.
} 
pencapaian kualitas kehidupan yang lebih tinggi bukan dipadamkan. Menurut Peter Mahmud Marzuki, damai sejahtera inilah yang merupakan tujuan hukum. ${ }^{13}$

Pandangan lebih luas dikemukakan oleh Theo Huijbers. ${ }^{14}$ Dalam pandangannya, tujuan hukum adalah untuk menciptakan suatu aturan masyarakat yang adil berdasarkan hak-hak manusia yang sejati. Tujuan ini hanya tercapai apabila pemerintah berpegang pada norma-norma keadilan, dan mewujudkan suatu aturan yang adil melalui undang-undang. Selanjutnya ia mengemukakan bahwa hukum berada di atas pemerintah, sehingga pemerintah harus bertindak sebagai abdi hukum. Pandangan ini lebih dekat dengan pandangan Apeldoorn yang mengemukakan bahwa tujuan hukum adalah tata tertib masyarakat yang damai dan adil. ${ }^{15}$

Pitlo berpendapat bahwa tujuan hukum adalah membawa keadilan dan ketenteraman dalam saling hubungan antara sesama manusia. ${ }^{16}$ Sementara Utrecht memandang tujuan hukum lebih kepada soal kepastian hukum. Menurutnya, tujuan hukum adalah untuk menjamin suatu kepastian di tengah-tengah masyarakat. Hanya keputusan yang dapat membuat kepastian hukum sepenuhnya. Maka hukum bersifat sebagai alat untuk mencapai kepastian hukum. ${ }^{17}$

Menurut Achmad Ali, tujuan hukum secara umum dapat diklasifikasikan ke dalam tiga aliran sebagai berikut: 18

1. Aliran etis yang menganggap pada asasnya tujuan hukum adalah untuk mencapai keadilan;

2. Aliran utilitis yang menganggap pada asasnya tujuan hukum adalah untuk menciptakan kemanfaatan; dan

3. Aliran yuridis formal yang menganggap pada asasnya tujuan hukum adalah untuk menciptakan kepastian hukum.

Sedangkan Suhardjo ${ }^{19}$ yang memandang tujuan hukum dalam perspektif Pancasila berpendapat bahwa tujuan hukum adalah untuk mengayomi manusia baik secara aktif maupun secara pasif. Secara aktif yakni menciptakan kondisi kemasyarakatan yang

13 Peter Mahmud Marzuki II, Op. Cit., h. 128-129.

14 Theo Huijbers, Filsafat Hukum, Kanisius, Yogyakarta, 1995, h. 114.

15 L.J. van Apeldoorn, Pengantar Ilmu Hukum, Terjemahan Oetarid Sadino, Pradnya Paramita, Jakarta, 1993, h. 16.

16 A. Pitlo, Suatu Pengantar: Azas-azas Hukum Perdata, Alumni, Bandung, 1973, h. 36.

17 Utrecht \& Moh. Saleh Jindang, Pengantar Dalam Hukum Indonesia, Ichtiar Baru, Jakarta, 1983, h. 14.

18 Achmad Ali, Tujuan dan Fungsi Hukum, Ghalia, Jakarta, 2001, h. 100-101.

19 Lihat Bernard Arief Sidharta, Ilmu Hukum Indonesia, Upaya Pengembangan Ilmu Hukum Sistematik Yang Responsif Terhadap Perubahan Masyarakat, Genta Publishing, Yogyakarta, 2013, h. 105. Lihat juga Abdul Manan, Aspek-Aspek Pengubah Hukum, Kencana Prenada Media, Jakarta, 2009, h. 23. 
manusiawi dalam proses yang berlangsung secara wajar, sehingga tiap manusia memperoleh kesempatan yang luas dan sama secara adil. Sedangkan secara pasif yakni mencegah tindakan sewenang-wenang dan penyalahgunaan hak secara tidak adil. Menurut Suhardjo, pelaksanaan pengayoman itu dilaksanakan dengan upaya mewujudkan:

1. Ketertiban dan keteraturan yang memunculkan prediktabilitas;

2. Kedamaian yang berketenteraman;

3. Keadilan bagi seluruh masyarakat;

4. Kesejahteraan dan keadilan sosial;

5. Pembinaan akhlak luhur berdasarkan Ketuhanan yang Maha Esa.

Dalam perspektif hukum Islam (syariah), tujuan hukum menurut Abu Hamid alGhazali dan Abu Ishaq asy-Syatibi adalah untuk mencapai kemaslahatan (kesejahteraan) masyarakat secara keseluruhan, baik di dunia maupun di akhirat. ${ }^{20}$ Untuk mencapai kemaslahatan tersebut diwujudkan dalam maqashid syariah ${ }^{21}$, yakni memelihara agama (hifzh al-din), memelihara kehidupan (hifzh al-nafs), memelihara akal (hifzh al-aql), memelihara keturunan (hifzh al-nasb) dan memelihara harta (hifzh al-maal). ${ }^{22}$ Kelima tujuan syariah tersebut merupakan sesuatu yang esensial (daruriyat), sehinga pengabaian salah satu dari lima maqashid tersebut akan membawa kehancuran akhlak dan tatanan sosial secara total. ${ }^{23}$

Dari beberapa pendapat tersebut di atas, secara sederhana dapat dikatakan bahwa tujuan hukum adalah untuk mengayomi masyarakat agar tercapai suatu kehidupan yang baik, adil, dan damai sejahtera, baik di dunia maupun di akhirat. Beranjak dari tujuan hukum tersebut, apabila dikaji dalam konteks hukum kontrak, maka

20 Fathurrahman Djamil, Hukum Ekonomi Islam, Sejarah, Teori dan Konsep, Sinar Grafika, Jakarta, 2013, h. 65. Lihat juga T.M. Hasby Ash-Shiddiqy, Falsafah Hukum Islam, Bulan Bintang, Yogyakarta, 1974, h. 181183 yang menulis, para ulama fiqh dan ushul fiqh sepakat bahwa hukum Islam diturunkan untuk kemaslahatan manusia di dunia maupun akhirat. ${ }^{20}$

21 Maqasid syariah adalah tujuan Allah dan Rasul-Nya dalam merumuskan hukum-hukum Islam. Tujuan itu dapat ditelusuri dalam ayat-ayat al-Qur'an dan hadis sebagai alasan logis bagi rumusan suatu hukum yang berorientasi kepada kemaslahatan manusia. Lihat Satria Effendi M. Zein, Ushul Fiqh, Kencana, Jakarta, 2005, h. 233. Sementara itu Wahbah al-Zuhaili mendefinisikan maqashid syariah dengan makna-makna dan tujuan-tujuan yang dipelihara oleh syara' dalam seluruh hukumnya atau sebagian besar hukumnya, atau tujuan akhir dari syariat dan rahasia-rahasia yang diletakkan oleh syara' pada setiap hukumnya. Lihat Ghofat Shidiq, "Teori Maqashid Al-Syari'ah Dalam Hukum Islam", Majalah Ilmiah Sultan Agung, Vol. XLIV No. 118, Juni-Agustus 2009, h. 119.

22 Habib Muhsin Syafingi, "Internalisasi Nilai-nilai Hukum Islam dalam Peraturan Daerah Syariah di Indonesia", Pandecta, Jurnal Penelitian Ilmu Hukum, Vol 7 No. 2, Juli 2012, h. 141.

23 Abd.Shomad, "Rekonstruksi Akad Bank Syariah Untuk Mencapai Kemaslahatan Sebagai Wujud Rahmatan Lil-Alamin”, dalam Moch. Isnaeni, Perkembangan Hukum Perdata di Indonesia, Laksbang Grafika, Yogyakarta, 2013, h. 111. 
dapat dikatakan bahwa tujuan hukum kontrak adalah untuk mengayomi atau melindungi kepentingan para pihak yang terikat dalam kontrak. Namun demikian, untuk sampai pada tujuan hukum itu, dibutuhkan suatu aturan-aturan dan kekuasaan yang adil. Hal ini dibutuhkan selain agar tidak terjadi tindakan sewenang-wenang dan penyalahgunaan hak secara tidak adil, juga agar terjamin suatu kepastian hukum di tengah-tengah masyarakat. Mengenai hal ini Lili Rasjidi dan Liza Sonia Rasjidi mengetengahkan beberapa teori yang dianggap penting, yaitu: ${ }^{24}$

1. Kedaulatan Tuhan (Teokrasi).

2. Teori Perjanjian Masyarakat (Kontrak sosial).

3. Teori Kedaulatan Negara.

4. Teori Kedaulatan Hukum.

Teori kedaulatan Tuhan berpandangan bahwa hukum sebagai kehendak Tuhan. Manusia sebagai salah satu ciptaan-Nya wajib taat pada hukum Ketuhanan. Teori ini menganggap bahwa raja adalah jelmaan Tuhan (seperti raja Fir'aun), atau wakil Tuhan di dunia, sehingga semua hukum yang dibuat raja harus pula ditaati oleh rakyatnya. ${ }^{25}$ Diantara penganut teori kedaulatan Tuhan yang modern adalah Friedrich Julius Stahl (1802-1861) dan Abu A'la al-Maududi (1903-1979). Stahl menyatakan bahwa kekuasaan tidak tumbuh disebabkan oleh manusia, melainkan disebabkan kehendak Tuhan. Sementara Maududi menyatakan bahwa kekuasaan tertinggi (kedaulatan) terdapat pada Allah, sedangkan umat manusia hanyalah pelaksana kedaulatan Allah sebagai khalifah di muka bumi. ${ }^{26}$

Selanjutnya teori perjanjian masyarakat. Teori ini berpandangan bahwa hukum sebagai kehendak bersama, suatu konsensus (perjanjian) dari segenap anggota masyarakat. Sehingga masyarakat harus taat dan tunduk pada hukum atas dasar perjanjian untuk menaatinya. ${ }^{27} \mathrm{Di}$ antara pendasar teori perjanjian masyarakat adalah Thomas Hobbes (1588-1679) dan J.J. Rousseau (1712-1778). Meskipun sama-sama pendasar teori perjanjian masyarakat, terdapat perbedaan pendapat di antara mereka, terutama terkait soal kekuasaan. Hobbes menekankan pendapatnya pada perjanjian penyerahan kekuasaan (pactum subjectionis). Menurut Hobbes, masyarakat secara

\footnotetext{
24 Lili Rasjidi dan Liza Sonia Rasjidi, Dasar-Dasar Filsafat dan Teori Hukum, Citra Aditya Bakti, Bandung, 2012, h. 82.

25 Ibid.

26 Deddy Ismatullah dan Asep A. Sahid Gatara Fh., Ilmu Negara Dalam Multi Perstektif, Kekuasaan, Masyarakat, Hukum, dan Agama, Pustaka Setia, Bandung, 2007, h. 58.

27 Lili Rasjidi dan Liza Sonia Rasjidi, Op. Cit., h. 83.
} 
alamiah menyerahkan haknya secara penuh kepada penguasa, sehingga kekuasaan penguasa bersifat absolut. ${ }^{28}$ Sedangkan J.J. Rousseau menekankan pendapatnya pada perjanjian persekutuan (pactum unionis). Menurut Rousseau, kekuasaan yang dimiliki oleh anggota masyarakat tetap berada pada individu-individu dan tidak diserahkan pada penguasa secara mutlak. ${ }^{29}$ Penguasa hanyalah wakil rakyat yang dibentuk berdasarkan kehendak rakyat (volonte general). ${ }^{30}$

Sementara teori kedaulatan negara mendasarkan kekuatan mengikat hukum pada kehendak negara, dan mendasarkan adanya kekuasaan negara itu sendiri pada sesuatu hukum kodrat, yang menyatakan bahwa yang lebih kuat menguasai yang lemah. Oleh daya hukum itulah maka terjadi negara, yang bukan buatan manusia, melainkan hasil alam. ${ }^{31}$ Hans Kelsen, mengemukakan bahwa hukum itu merupakan "wille des staates". Orang tunduk pada hukum karena merasa wajib menaatinya, karena hukum itu adalah kehendak negara. ${ }^{32}$

Sedangkan teori kedaulatan hukum berpandangan bahwa hukum mengikat bukan karena negara menghendakinya, melainkan karena merupakan perumusan dari kesadaran hukum rakyat. Berlakunya hukum adalah karena nilai batinnya yang menjelma di dalam hukum. Pendapat ini dikemukakan oleh Mr. H. Krabbe dalam bukunya "Die Lehre der Rechtssouveranitat". Selanjutnya Krabbe mengemukakan bahwa kesadaran hukum yang dimaksud adalah berpangkal pada perasaan hukum setiap individu, yaitu perasaan bagaimana seharusnya hukum itu. ${ }^{33}$ Dalam teori kedaulatan hukum, semua harus tunduk pada hukum, termasuk penguasa.

Terlepas dari adanya perbedaan pendapat soal bentuk kekuasaan, dari teori-teori di atas dapat disimpulkan bahwa hukum menghendaki eksistensi suatu penguasa, yang secara alamiah memiliki tugas dan wewenang untuk membuat dan mengawasi pelaksanaan hukum. Al-Ghazali mengemukakan, bahwa untuk memenuhi kebutuhan hidup rakyat, seperti ketertiban, keamanan, dan kesejahteraan, diperlukan unsur kekuasaan politik (siyasah). Kekuasaan ini dibutuhkan untuk mengelola negara, mengatur kerjasama antar warga negara, menjamin kepentingan bersama,

Deddy Ismatullah dan Asep A. Sahid Gatara Fh., Op.Cit., h. 65.

Lili Rasjidi dan Liza Sonia Rasjidi, Loc. Cit.

30 Deddy Ismatullah dan Asep A. Sahid Gatara Fh., Loc. Cit.

31 L.J. van Apeldoorn, Op. Cit., h. 435.

32 Lili Rasjidi dan Liza Sonia Rasjidi, Op. Cit., h. 84.

33 Ibid. 
menyelesaikan sengketa antara mereka, dan melindungi ancaman serta bahaya yang datang dari luar. ${ }^{34}$

Beranjak dari pemahaman tersebut di atas, dapat dikatakan bahwa yang memiliki tugas dan wewenang untuk membuat dan mengawasi pelaksanaan aturan-aturan hukum adalah kekuasaan negara. ${ }^{35}$ Karena kekuasaan negara adalah manifestasi dari kehendak rakyat yang berpangkal pada kehendak Tuhan. ${ }^{36}$ Tugas dan wewenang kekuasaan negara ini adalah semata-mata dimaksudkan untuk mengayomi masyarakat secara keseluruhan, agar tercapai suatu kehidupan yang baik, adil, dan damai sejahtera.

Dalam konteks hukum kontrak, tugas dan wewenang kekuasaan negara adalah untuk mengayomi para pihak yang telah terikat pada suatu kontrak. Entitas mengayomi ini menjelma dalam dua bentuk, yaitu:

1. Memberikan perlindungan terhadap kepentingan para pihak secara adil (fairness); dan

2. Memberikan kepastian hukum terhadap kontrak.

Perlindungan yang diberikan oleh kekuasaan negara terhadap kepentingan para pihak tersebut pada prosesnya mengejawantah dalam aturan-aturan hukum, dan diekspresikan oleh hakim sebagai representasi dari kekuasaan negara ketika terjadi sengketa. Mengenai hal ini Paul Scholten mengemukakan bahwa hukum berkulminasi dalam peradilan atau proses pengucapan hukum (rechtspraak). Hukum harus diucapkan untuk mentransformasi perintah yang abstrak dari faktor-faktor pembentukan hukum ke dalam kenyataan konkret. ${ }^{37}$

34 Deddy Ismatullah dan Asep A. Sahid Gatara Fh., Op.Cit., h. 25.

35 Dalam teori Trias Politika, Montesquieu membagi kekuasaan negara secara horisontal, yang terdiri atas tiga cabang kekuasaan, yaitu: cabang kekuasaan legislatif (kekuasaan untuk membuat undang-undang), cabang kekuasaan eksekutif (kekuasaan untuk melaksanakan undang-undang), dan cabang kekuasaan yudikatif (kekuasaan untuk mengadili pelanggaran undang-undang). Lihat Luthfi Widagdo Eddyono, "Penyelesaian Sengketa Kewenangan Lembaga Negara oleh Mahkamah Konstitusi", Jurnal Konstitusi, Vol. 7 No. 3, Juni 2010, h. 12.

36 Dalam hal ini penulis mengacu pada eksistensi takdir. Bahwa segala peristiwa yang terjadi di alam raya pada hakekatnya adalah merupakan ketetapan Tuhan. Quraish Shihab menjelaskan bahwa takdir berasal dari akar kata qadara yang berarti mengukur, memberi kadar atau ukuran. selanjutnya dicontohkan, jika dikatakan bahwa Allah telah menakdirkan demikian, maka berarti Allah telah memberi kadar, ukuran, atau batas tertentu dalam diri, sifat, atau kemampuan maksimal dari makhlukNya. Istilah takdir mirip dengan sunnatullah atau hukum alam, tetapi takdir setingkat di atasnya, karena hukum-hukumnya tidak hanya terjadi pada alam, melainkan juga pada hukum-hukum kemasyarakatan. Lihat M. Quraish Shihab, Wawasan al-Quran, Mizan, Bandung, 1996, h. 61-65.

37 Paul Scholten, Struktur Ilmu Hukum, Terjemahan B. Arief Sidharta, Alumni, Bandung, 2013, h. 39. 
Pendapat senada dikemukakan Sudikno Mertokusumo. ${ }^{38}$ Dalam pandangannya, tertib hukum harus ditegakkan, dan konflik kepentingan yang terjadi di masyarakat harus segera diselesaikan. Tidak boleh membiarkan konflik berlarut-larut dan berkepanjangan. Selanjutnya ia mengemukakan, bahwa untuk menyelesaikan konflik kepentingan, disyaratkan adanya lembaga peradilan (judicature, rechtspraak) yang bebas dan mandiri serta tidak berpihak, sehingga dapat menyelesaikan konflik kepentingan yang terjadi di masyarakat secara obyektif.

Gilbert Guillaume berpendapat bahwa the primary function of the judge is to adjudicate disputes. ${ }^{39}$ Hakim berfungsi untuk mengadili dan memutus siapa yang benar dan siapa yang tidak benar. ${ }^{40}$ Menurut Koesnoe, tugas hakim ialah menentukan bagaimana hukumnya bagi sesuatu persoalan hukum konkrit yang dihadapkan kepadanya, untuk kemudian dilekatkan akibat hukumnya. ${ }^{41}$ Dalam menjalankan tugas judisialnya, hakim tidak boleh memihak kepada siapa pun juga kecuali hanya kepada kebenaran dan keadilan. ${ }^{42}$ Richard A. Posner menulis, for the judge, the duty to decide the case and to do so, moreover, with reasonable dispatch is primary. ${ }^{43}$

Dari eksplikasi di atas maka dapat dikemukakan bahwa hakikat kewenangan hakim mengadili sengketa kontrak adalah selaras dengan tujuan hukum kontrak, yaitu untuk mengayomi pihak-pihak yang bersengketa, dengan memberikan perlindungan terhadap kepentingan para pihak secara adil (fairness), dan memberikan kepastian hukum terhadap kontrak yang disengketakan.

\section{Dasar Kewenangan Hakim Mengadili Sengketa Kontrak}

Secara yuridis, dasar kewenangan hakim dalam mengadili sengketa diatur dalam ketentuan Pasal 10 ayat (1) Undang-Undang Nomor 48 Tahun 2009 tentang Kekuasaan Kehakiman, dan Pasal 50 Undang-Undang Nomor 2 Tahun 1986 tentang Peradilan Umum, sebagaimana telah diubah terakhir dengan Undang-Undang Nomor 49 Tahun

38 Sudikno Mertokusumo, Teori Hukum, Universitas Atma Jaya, Yogyakarta, 2011, h. 21.

39 Gilbert Guillaume, "The Use of Precedent by International Judges and Arbitrators", Journal of International Dispute Settlement, Vol 2, No. 1, Oxford University Press, 2011, p. 6.

40 Lihat Retnowulan Sutantio dan Iskandar Oeripkartawinata, Hukum Acara Perdata Dalam Teori Dan Praktek, Mandar Maju, Bandung, 2009, h. 10.

41 Mohammad Koesnoe, "Hukum dan Perubahan-Perubahan Perhubungan Kemasyarakatan", Pidato pengukuhan Guru Besar, pada Fakultas Hukum Universitas Airlangga, Surabaya, 1967, h. 14.

42 Jimly Asshiddiqie, "Gagasan Negara Hukum Indonesia”, Majalah Hukum Nasional, Badan Pembinaan Hukum Nasional, Jakarta, No.1 Tahun 2012, h. 6.

43 Richard A. Posner, "The Role of The Judge in The Twenty-First Century", Boston University Law Review, Vol. 86, 2006, p. 1053. 
2009 tentang Perubahan Kedua Atas Undang-Undang Nomor 2 Tahun 1986 tentang Peradilan Umum.

Dalam Pasal 10 ayat (1) Undang-Undang Nomor 48 Tahun 2009 tentang Kekuasaan Kehakiman disebutkan bahwa "Pengadilan dilarang menolak untuk memeriksa, mengadili, dan memutus suatu perkara yang diajukan dengan dalih bahwa hukum tidak ada atau kurang jelas, melainkan wajib untuk memeriksa dan mengadilinya".

Selanjutnya dalam Pasal 50 Undang-Undang Nomor 2 Tahun 1986 tentang Peradilan Umum, sebagaimana telah diubah terakhir dengan Undang-Undang Nomor 49 Tahun 2009 tentang Perubahan Kedua Atas Undang-Undang Nomor 2 Tahun 1986 tentang Peradilan Umum, disebutkan bahwa "Hakim bertugas dan berwenang memeriksa, memutus dan menyelesaikan perkara". Bahkan secara filosofis, teoritik maupun dogmatik, hakim dapat secara aktif dalam menegakkan hukum dan keadilan melalui proses peradilan perdata. Sengketa kontrak adalah merupakan sengketa perdata. ${ }^{44}$ Dengan demikian, secara yuridis hakim memiliki kewenangan untuk mengadili sengketa kontrak.

Namun demikian, dalam konteks sengketa kontrak, kewenangan hakim dalam memeriksa, mengadili dan memutus sengketa kontrak tidaklah absolut. Kewenangan hakim dibatasi oleh ketentuan Pasal 3 Undang-Undang Nomor 30 Tahun 1999 tentang Arbitrase dan Penyelesaian Sengketa, yang menyebutkan bahwa "Pengadilan Negeri tidak berwenang untuk mengadili sengketa para pihak yang telah terikat dalam perjanjian arbitrase". Bahkan di dalam Pasal 11 ayat (2) ditegaskan bahwa "Pengadilan Negeri wajib menolak dan tidak akan campur tangan di dalam suatu penyelesaian sengketa yang telah ditetapkan melalui arbitrase, kecuali dalam hal-hal tertentu yang ditetapkan dalam Undang-Undang Arbitrase".

\section{Kewenangan Memeriksa, Mengadili, dan Memutus Sengketa}

Di dalam sistem hukum Indonesia, konsep menerima, memeriksa, mengadili, memutus dan menyelesaikan sengketa, belum memiliki makna baku. Padahal konsep-konsep tersebut berkaitan dengan tugas dan wewenang pengadilan. Belum adanya kesatuan makna berakibat pada penggunaan konsep yang tidak selaras dalam rumusan undangundang. Beberapa undang-undang menggunakan konsep-konsep tersebut secara bersamaan, sementara beberapa yang lain hanya menggunakan sebagian dari konsep

44 Sunarto, "Prinsip Hakim Bersifat Aktif Dalam Perkara Perdata”, Disertasi, Program Doktor Ilmu Hukum Fakultas Hukum Universitas Airlangga, Surabaya, 2012, h. 353. 
tersebut. Ketidakselarasan penggunaan konsep-konsep tersebut dalam undang-undang, setidaknya dapat mengaburkan tugas dan wewenang hakim dalam menyelesaikan sengketa yang dihadapkan kepadanya. Rumusan yang terkait dengan tugas dan wewenang hakim dalam undang-undang ialah sebagai berikut:

- Undang-Undang Nomor 8 Tahun 1981 tentang Hukum Acara Pidana.

"Dalam Pasal 84 ayat (1) dirumuskan: Pengadilan Negeri berwenang mengadili segala perkara mengenai tindak pidana yang dilakukan dalam daerah hukumnya".

(Garis bawah dari penulis).

- Undang-Undang Nomor 14 Tahun 1985 tentang Mahkamah Agung.

"Dalam Pasal 28 ayat (1) dirumuskan: Mahkamah Agung bertugas dan berwenang memeriksa dan memutus:

a. permohonan kasasi;

b. sengketa tentang kewenangan mengadili;

c. permohonan peninjauan kembali.....dst".

(Garis bawah dari penulis).

- Undang-Undang Nomor 2 Tahun 1986 tentang Peradilan Umum.

"Dalam Pasal 50 dirumuskan: Pengadilan Negeri bertugas dan berwenang memeriksa, memutus, dan menyelesaikan perkara pidana dan perkara perdata di tingkat pertama".

(Garis bawah dari penulis).

- Undang-Undang Nomor 5 Tahun 1986 tentang Peradilan Tata Usaha Negara.

"Dalam Pasal 47 dirumuskan: Pengadilan bertugas dan berwenang memeriksa memutus, dan menyelesaikan sengketa Tata Usaha Negara".

(Garis bawah dari penulis).

- Undang-Undang Nomor 7 Tahun 1989 tentang Peradilan Agama sebagaimana telah diubah terakhir dengan Undang-Undang Nomor 50 Tahun 2009 tentang Perubahan Kedua Atas Undang-Undang Nomor 7 Tahun 1989 tentang Peradilan Agama.

"Dalam Pasal 49 ayat (1) dirumuskan: Pengadilan Agama bertugas dan berwenang memeriksa, memutus, dan menyelesaikan perkara di tingkat pertama antara orang-orang yang beragama Islam di bidang:

a. perkawinan;

b. waris;

c. wasiat; .....dst".

(Garis bawah dari penulis).

- Undang-Undang Nomor 30 Tahun 1999 tentang Arbitrase Dan Alternatif Penyelesaian Sengketa. 
"Dalam Pasal 3 dirumuskan: Pengadilan Negeri tidak berwenang untuk mengadili sengketa para pihak yang telah terikat dalam perjanjian arbitrase".

(Garis bawah dari penulis).

- Undang-Undang Nomor 30 Tahun 2002 tentang Komisi Pemberantasan Tindak Pidana Korupsi.

"Dalam Pasal 53 dirumuskan: Dengan Undang-Undang ini dibentuk Pengadilan Tindak Pidana Korupsi yang bertugas dan berwenang memeriksa dan memutus tindak pidana korupsi yang penuntutannya diajukan oleh Komisi Pemberantasan Korupsi".

(Garis bawah dari penulis).

- Undang-Undang Nomor 2 Tahun 2004 tentang Penyelesaian Perselisihan hubungan Industrial.

"Dalam Pasal 1 angka 17 dirumuskan: Pengadilan Hubungan Industrial adalah pengadilan khusus yang dibentuk di lingkungan pengadilan negeri yang berwenang memeriksa, mengadili dan memberi putusan terhadap perselisihan hubungan industrial".

(Garis bawah dari penulis).

- Undang-Undang Nomor 37 Tahun 2004 tentang Kepailitan Dan Penundaan Kewajiban Pembayaran Utang.

"Dalam Pasal 300 ayat (1) dirumuskan: Pengadilan sebagaimana dimaksud dalam Undang-Undang ini, selain memeriksa dan memutus permohonan pernyataan pailit dan Penundaan Kewajiban Pembayaran Utang, berwenang pula memeriksa dan memutus perkara lain di bidang perniagaan yang penetapannya dilakukan dengan undang-undang".

(Garis bawah dari penulis).

- Undang-Undang Nomor 48 Tahun 2009 tentang Kekuasaan Kehakiman.

"Dalam Pasal 25 ayat (2) dirumuskan: Peradilan umum sebagaimana dimaksud pada ayat (1) berwenang memeriksa, mengadili, dan memutus perkara pidana dan perdata sesuai dengan ketentuan peraturan perundang-undangan".

"Sedangkan dalam Pasal 25 ayat (3) dirumuskan: Peradilan agama sebagaimana dimaksud pada ayat (1) berwenang memeriksa mengadili, memutus, dan menyelesaikan perkara antara orang-orang yang beragama Islam sesuai dengan ketentuan peraturan perundang-undangan".

(Garis bawah dari penulis).

- Undang-Undang Nomor 11 Tahun 2012 tentang Sistem Peradilan Pidana Anak.

"Dalam Pasal 44 ayat (1) dirumuskan: Hakim memeriksa dan memutus perkara Anak dalam tingkat pertama dengan hakim tunggal".

(Garis bawah dari penulis).

Dari rumusan pasal dalam undang-undang di atas terlihat inkonsistensi pembuat undang-undang dalam merumuskan tugas dan wewenang hakim. Selain tidak konsisten 
dalam menyebutkan tugas-tugas dan wewenang hakim, dalam undang-undang juga tidak didefinisikan secara jelas apa yang dimaksud dengan konsep menerima, memeriksa, mengadili, memutus dan menyelesaikan perkara. Sementara di dalam penjelasan hanya disebutkan cukup jelas.

Diantara lima konsep tugas dan wewenang hakim, hanya konsep "mengadili” yang telah didefinisikan dalam undang-undang. Pada Pasal 1 angka 9 Undang-Undang Nomor 8 Tahun 1981 tentang Hukum Acara Pidana, dirumuskan bahwa "Mengadili adalah serangkaian tindakan hakim untuk menerima, memeriksa dan memutus perkara pidana berdasarkan asas bebas, jujur, dan tidak memihak di sidang pengadilan dalam hal dan menurut cara yang diatur dalam undang-undang ini".

Dari definisi konsep mengadili tersebut, terlihat sudah mencakup juga konsep menerima, memeriksa dan memutus perkara. Maka jika bersandar pada pengertian konsep mengadili tersebut, tugas dan wewenang hakim cukup dirumuskan dengan mengadili, tanpa perlu menyebut konsep-konsep lainnya. Tetapi implementasinya akan rancu, terutama apabila dihadapkan pada perkara yang bukan merupakan wewenang hakim. Misalnya dalam perkara sengketa kontrak yang di dalamnya terdapat perjanjian arbitrase. Memang pada dasarnya hakim tetap berwenang menerima dan memberikan putusan, meskipun putusan yang dijatuhkan menyatakan gugatan tidak dapat diterima (niet ontvankelijke verklaard). Tetapi hakim tidak memiliki wewenang untuk mengadili, karena wewenang mengadili sengketa berada pada lembaga arbitrase.

Terlepas dari beragamnya konsep kewenangan yang dimiliki hakim, pada dasarnya hakim memiliki kewenangan untuk menerima, memeriksa, mengadili, memutus dan menyelesaikan semua perkara yang dihadapkan kepadanya. Kewenangan tersebut didasarkan pada ketentuan Pasal 50 Undang-Undang Nomor 2 Tahun 1986 tentang Peradilan Umum, sebagaimana telah diubah terakhir dengan Undang-Undang Nomor 49 Tahun 2009 tentang Perubahan Kedua Atas Undang-Undang Nomor 2 Tahun 1986 tentang Peradilan Umum jo. Pasal 10 ayat (1) Undang-Undang Nomor 48 Tahun 2009 tentang Kekuasaan Kehakiman.

\section{KESIMPULAN}

Dasar kewenangan hakim mengadili sengketa kontrak ialah sebagai berikut :

Secara filosofis kewenangan didasarkan pada tujuan hukum kontrak, yaitu untuk mengayomi pihak-pihak yang bersengketa, dengan memberikan perlindungan terhadap 
kepentingan para pihak secara adil (fairness), dan memberikan kepastian hukum terhadap kontrak yang disengketakan.

Secara yuridis kewenangan hakim didasarkan pada ketentuan-ketentuan Pasal 50 Undang-Undang Nomor 2 Tahun 1986 tentang Peradilan Umum, sebagaimana telah diubah terakhir dengan Undang-Undang Nomor 49 Tahun 2009 tentang Perubahan Kedua Atas Undang-Undang Nomor 2 Tahun 1986 tentang Peradilan Umum, yang menegaskan bahwa hakim bertugas dan berwenang memeriksa, memutus dan menyelesaikan perkara. Jo. ketentuan Pasal 10 ayat (1) Undang-Undang Nomor 48 Tahun 2009 tentang Kekuasaan Kehakiman, yang menegaskan bahwa hakim dilarang menolak untuk memeriksa, mengadili, dan memutus suatu perkara yang diajukan dengan dalih bahwa hukum tidak ada atau kurang jelas, melainkan wajib untuk memeriksa dan mengadilinya.

\section{Daftar Pustaka}

\section{Peraturan Perundang-undangan}

Burgerlijk Wetboek Stb. 1847-23

Undang-Undang No. 8 Tahun 1981 tentang Hukum Acara Pidana (Lembaran Negara RI Tahun 1981 Nomor 76, Tambahan Lembaran Negara RI Nomor 3209)

Undang-Undang No. 14 Tahun 1985 tentang Mahkamah Agung, sebagaimana telah diubah terakhir dengan Undang-Undang Nomor 3 Tahun 2009 tentang Perubahan Kedua Atas Undang-Undang Nomor 14 Tahun 1985 tentang Mahkamah Agung (Lembaran Negara RI Tahun 2009 Nomor 3, Tambahan Lembaran Negara RI Nomor 4958)

Undang-Undang No. 2 Tahun 1986 tentang Peradilan Umum, sebagaimana telah diubah terakhir dengan Undang-Undang Nomor 49 Tahun 2009 tentang Perubahan Kedua Atas Undang-Undang Nomor 02 Tahun 1986 tentang Peradilan Umum (Lembaran Negara RI Tahun 2009 Nomor 158, Tambahan Lembaran Negara RI Nomor 5077)

Undang-Undang No. 5 Tahun 1986 tentang Peradilan Tata Usaha Negara (Lembaran Negara RI Tahun 1986 Nomor 77, Tambahan Lembaran Negara RI Nomor 3344) Undang-Undang No. 7 Tahun 1989 tentang Peradilan Agama, sebagaimana telah diubah terakhir dengan Undang-Undang No. 50 Tahun 2009 tentang Perubahan Kedua 
Atas Undang-Undang No. 7 Tahun 1989 tentang Peradilan Agama (Lembaran

Negara RI Tahun 2009 Nomor 159, Tambahan Lembaran Negara RI Nomor 5078)

Undang-Undang No. 30 Tahun 1999 tentang Arbitrase Dan Alternatif Penyelesaian

Sengketa (Lembaran Negara RI Tahun 1999 Nomor 138, Tambahan Lembaran

Negara RI Nomor 3872)

Undang-Undang No. 30 Tahun 2002 tentang Komisi Pemberantasan Tindak Pidana

Korupsi (Lembaran Negara RI Tahun 2002 Nomor 137, Tambahan Lembaran

Negara RI Nomor 4250)

Undang-Undang No. 2 Tahun 2004 tentang Penyelesaian Perselisihan hubungan

Industrial (Lembaran Negara RI Tahun 2004 Nomor 6, Tambahan Lembaran Negara RI Nomor 4356)

Undang-Undang No. 37 Tahun 2004 tentang Kepailitan Dan Penundaan Kewajiban

Pembayaran Utang (Lembaran Negara RI Tahun 2004 Nomor 131, Tambahan Lembaran Negara RI Nomor 4443)

Undang-Undang No. 48 Tahun 2009 tentang Kekuasaan Kehakiman (Lembaran Negara RI

Tahun 2009 Nomor 157, Tambahan Lembaran Negara RI Nomor 5076)

Undang-Undang No. 11 Tahun 2012 tentang Sistem Peradilan Pidana Anak (Lembaran

Negara RI Tahun 2012 Nomor 153, Tambahan Lembaran Negara RI Nomor 5332)

Putusan Mahkamah Agung R.I. No. 289 K/Sip/1972, tanggal 22 Juli 1972, dalam perkara Ida Ayu Suryani melawan I Nyoman Sudirja.

Putusan Mahkamah Agung R.I. No. 791 K/Sip/1972, tanggal 23 Pebruari 1972, dalam perkara Can Thiam Song melawan Cia Khun Chai.

Putusan Mahkamah Agung R.I. No. 1253 K/Sip/1973, tanggal 14 Oktober 1976, dalam perkara Zainal Abidin melawan A.M. Mohamad Zainuddin dkk.

Putusan Mahkamah Agung R.I. No. 3641 K/PDT/2001, tanggal 11 September 2001, dalam perkara Made Oka Masagung melawan PT Bank Artha Graha, dkk.

\section{Buku}

Ali, Achmad, Tujuan dan Fungsi Hukum, Jakarta: Ghalia 2001.

Ash-Shiddiqy, T.M. Hasby, Falsafah Hukum Islam, Yogyakarta: Bulan Bintang 1974.

Djamil, Fathurrahman, Hukum Ekonomi Islam, Sejarah, Teori dan Konsep, Jakarta: Sinar Grafika 2013. 
Erwin: Muhammad, Filsafat Hukum Refleksi Kritis Terhadap Hukum, Jakarta: RajaGrafindo 2011.

Hartkamp, Arthur S., Marianne M.M. Tillema and Annemarie E.B. ter Heide, Contract Law in the Netherlands, Alphen aan den Rijn: Kluwer Law International 2011.

HS Salim, Hukum Kontrak: Teori \& Teknik Penyusunan Kontrak, Cet. Kesepuluh, Jakarta: Sinar Grafika 2014.

------, Pengantar Hukum Perdata Tertulis $(B W)$, Cet. Kesembilan, Jakarta: Sinar Grafika 2014.

Huijbers, Theo, Filsafat Hukum, Yogyakarta: Kanisius 1995.

Ismatullah, Deddy dan Asep A. Sahid Gatara Fh., Ilmu Negara Dalam Multi Perstektif, Kekuasaan, Masyarakat, Hukum, dan Agama, Bandung: Pustaka Setia 2007.

Koesnoe, Mohammad, Hukum dan Perubahan-Perubahan Perhubungan Kemasyarakatan, Pidato Pengukuhan Guru Besar, Surabaya: Fakultas Hukum Universitas Airlangga 1967.

L.J. van Apeldoorn, Pengantar Ilmu Hukum, Terjemahan Oetarid Sadino, Jakarta: Pradnya Paramita 1993.

Manan, Abdul, Aspek-Aspek Pengubah Hukum, Jakarta: Kencana Prenada Media 2009.

Marzuki, Peter Mahmud, Pengantar Ilmu Hukum, Edisi Revisi, Jakarta: Kencana Prenada Media Group 2013.

Mertokusumo, Sudikno, Teori Hukum, Yogyakarta: Universitas Atma Jaya 2011.

Meuwissen, Tentang Pengembangan Hukum, Ilmu Hukum, Teori Hukum, dan Filsafat Hukum, Terjemahan B. Arief Sidharta, Bandung: Refika Aditama 2013.

Nieuwenhuis, J.H., Drie Beginselen van Contractenrecht, Deventer: Kluwer 1979.

------, Pokok-Pokok Hukum Perikatan, Terjemahan Djasadin Saragih, Surabaya: Universitas Airlangga 1985.

Pitlo, A., Suatu Pengantar: Azas-azas Hukum Perdata, Bandung: Alumni, 1973.

Rasjidi, Lili dan Liza Sonia Rasjidi, Dasar-Dasar Filsafat dan Teori Hukum, Bandung: Citra Aditya Bakti 2012.

Scholten, Paul, Struktur Ilmu Hukum, Terjemahan B. Arief Sidharta, Bandung: Alumni 2013.

Shihab, M. Quraish, Wawasan al-Quran, Bandung: Mizan 1996. 
Shomad, Abd., "Rekonstruksi Akad Bank Syariah Untuk Mencapai Kemaslahatan Sebagai Wujud Rahmatan Lil-Alamin", dalam Moch. Isnaeni, Perkembangan Hukum Perdata di Indonesia, Laksbang Grafika, Yogyakarta, 2013

Sidharta, Bernard Arief, Ilmu Hukum Indonesia, Upaya Pengembangan Ilmu Hukum Sistematik Yang Responsif Terhadap Perubahan Masyarakat, Yogyakarta: Genta Publishing 2013.

Subekti, R., Aneka Perjanjian, Cet. Kesepuluh, Bandung: Citra Aditya Bakti 1995.

Sunarto, Prinsip Hakim Bersifat Aktif Dalam Perkara Perdata, Disertasi, Surabaya: Program Doktor Ilmu Hukum Fakultas Hukum Universitas Airlangga 2012.

Sutantio, Retnowulan dan Iskandar Oeripkartawinata, Hukum Acara Perdata Dalam Teori dan Praktek, Bandung: Mandar Maju 2009.

Utrecht \& Moh. Saleh Jindang, Pengantar Dalam Hukum Indonesia, Jakarta: Ichtiar Baru 1983.

Zein, Satria Effendi M., Ushul Fiqh, Jakarta: Kencana 2005.

\section{Jurnal}

Asshiddiqie, Jimly, “Gagasan Negara Hukum Indonesia”, Majalah Hukum Nasional, Badan Pembinaan Hukum Nasional, Jakarta, No.1 Tahun 2012

Eddyono, Luthfi Widagdo, "Penyelesaian Sengketa Kewenangan Lembaga Negara oleh Mahkamah Konstitusi”, Jurnal Konstitusi, Vol. 7 No. 3, Juni 2010

Guillaume, Gilbert, "The Use of Precedent by International Judges and Arbitrators", Journal of International Dispute Settlement, Vol 2, No. 1, 2011

Khairandy, Ridwan, “Landasan Filosofis Kekuatan Mengikatnya Kontrak”, Jurnal Hukum, No. Edisi Khusus Vol. 18, Oktober 2011

Marzuki, Peter Mahmud, "Batas-Batas Kebebasan Berkontrak”, Yuridika, Vol. 18 No. 3, Mei 2003

Posner, Richard A., "The Role of The Judge in The Twenty-First Century", Boston University Law Review, Vol. 86, 2006

Shidiq, Ghofat, “Teori Maqashid Al-Syari'ah Dalam Hukum Islam”, Majalah Ilmiah Sultan Agung, Vol. XLIV No. 118, Juni-Agustus 2009

Syafingi, Habib Muhsin, "Internalisasi Nilai-nilai Hukum Islam dalam Peraturan Daerah Syariah di Indonesia", Pandecta, Jurnal Penelitian Ilmu Hukum, Vol 7 No. 2, Juli 2012 